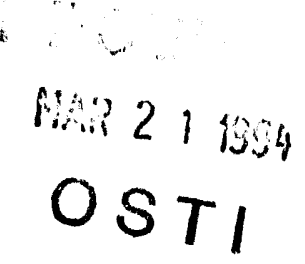

\title{
STABLE ISOTOPE VARIATIONS IN BANDED IRON FORMATIONS
}

T. A. Abrajano, Jr. and B. D. Holt, Geoscience Group, Chemical Technology Division, Argonne National Laboratory, 9700 South Cass Avenue, Argonne, IL 60439, USA

$$
\begin{aligned}
& \text { The submitted manuscript has been authored } \\
& \text { by a contractor of the U.S. Government } \\
& \text { under contract No. W-31-109-ENG-38. } \\
& \text { Accordingly, the U. S. Government retains a } \\
& \text { nonexclusive, royalty-free license to publish } \\
& \text { or reproduce the published form of this } \\
& \text { contribution, or allow others to do so, for } \\
& U \text {. S. Government purposes. }
\end{aligned}
$$

Submitted for Consideration to:

NATURE

March 18, 1991

Work supported by the U.S. Department of Energy, Office of Basic Energy Sciences, under Contract W-31-109-Eng-38. 
Stable Isotope Variations in Banded Iron Formations

T. A. Abrajano, Jr. and B. D. Holt, Geoscience Group, Chemical Technology Division, Argonne National Laboratory, 9700 South Cass Avenue, Argonne, IL 60439, USA

In spite of the significant amount of work already reported in the scientific literature, many aspects of the origin of Banded Iron Formations (BIF) remain enigmatic. We demonstrate that mineralogic microbanding in BIF is accompanied by autocorrelated isotopic microbanding of organic carbon and carbonate carbon and oxygen. We propose that these isotopic patterns formed as a result of episodic mixing of waters in the depositional environment of BIF.

The isotopic record preserved in Precambrian rocks is of extreme importance in understanding geologic, biologic, and atmospheric conditions that prevailed in pre-Phanerozoic times ${ }^{1,2}$. Banded Iron Formations, which are iron-rich chemical sediments formed largely before about 1.7 billion years ago, provide some of the most interesting evidence of this early part of Earth history. Previous workers have noted significant depletion of ${ }^{13} \mathrm{C}$ in carbonates from BIF ${ }^{3-6}$. In some cases, this depletion occurred in the same period when global enrichment of ${ }^{13} \mathrm{C}$ in seawater has been proposed to exist ${ }^{7,8}$. There is now a consensus that recycling of organic matter contributed to the ${ }^{13} \mathrm{C}$-depleted carbon poo' from which BIF carbonates precipitated ${ }^{3-6}$.

It is widely accepted that microbanding in BIF formed as a consequence of episodic changes in the environment of deposition ${ }^{9}$. Baur et al. ${ }^{6}$ were first to point out that these microbanding features in BIF are also characterized by rhythmic variations in carbon and oxygen isotopic compositions of carbonates. In this paper, we will show that these rhythmic isotopic patterns in carbonates occur in the Biwabik Iron Formation (Minnesota), and that autocorrelated patterns are also exhibited by the total organic carbon 
abundance and isotopic composition. The isotopic patterns, as well as the mineralogic and chemical variations, support a model for BIF origin that involves episodic mixing of waters in the depositional environment.

A 3-cm cross-section of an Intermediate Slate sample from the Biwabik Iron Formation (MDO 5-924) was sectioned to isolate the light and dark bands (Figure 1). At least nine major bands can be observed in the hand specimen. $X$-ray diffraction and optical microscopy revealed that the lighter bands are dominated by siderite $\left(\mathrm{FeCO}_{3}\right)$, whereas the darker bands are dominated by quartz $\left(\mathrm{SiO}_{2}\right)$. Both minerals are, however, present in both types of bands together with ubiquitous but trace amounts of dolomitic ankerite $\left(\mathrm{Ca}(\mathrm{Mg}, \mathrm{Fe})\left(\mathrm{CO}_{3}\right)_{2}\right)$. X-ray diffraction analyses of demineralized $(\mathrm{HF} / \mathrm{HCl}$ dissolution) bulk samples also revealed the presence of amorphous kerogen and pyrite. Under the microscope, pyrite, kerogen and rare hematite grains are clearly associated with the quartz-rich bands and are responsible for the dark coloration. A total of 18 slices from the sample were analyzed following a procedure described previously 10 .

Figure 2 summarizes the chemical and isotopic variations across MDD 5-924 (see Figure 1). The autocorrelation of $\mathrm{Fe}, \mathrm{Ca}, \mathrm{Mn}$, and $\mathrm{Mg}$ reflects their common affinity for the carbonate-rich bands. The $\mathrm{Mg} / \mathrm{Fe}$ ratio was observed to be higher in the carbonate-rich bands than in the quartz-rich bands. The $\mathrm{Mg} / \mathrm{Fe}$ ratio also appears to increase systematically from the base of a quartz-rich band (e.g. band 3) to the base of the next overlying quartz-rich band (e.g. band 5) (Figure $2 \mathrm{e}$, dashed 1 ines). The antithetic relation between total carbonate and total organic carbon (Figure $2 f, g$ ) confirms the microscopic observation already noted earlier. 
Distinct isotopic variations in carbonate carbon and oxygen across the bands are observed (Figure $2 h, i)$. Carbonate-rich bands tend to be enriched in ${ }^{13} \mathrm{C}$ and ${ }^{18} 0$ relative to adjacent quartz-rich bands with an average difference of 0.7 per mil for $\delta^{13} \mathrm{C}$ and 1.5 per mil for $\delta^{18} 0$. This autocorrelation between $\delta^{13} \mathrm{C}$ and $\delta^{18} 0$ was observed previously in microbanded BIF samples from the Hamersley Basin ${ }^{6}$, where the average isotopic contrast between adjacent microbands is 3 per mil for $\delta^{13} \mathrm{C}$ and 3.1 per mil for $\delta^{18} 0$. Figure $2 j$ shows that $\delta^{13} \mathrm{C}$ value of the organic carbon fraction is also autocorrelated to the $\delta^{13} \mathrm{C}$ value of the carbonates. This correlation has not been observed previously.

Baur et al. ${ }^{6}$ and Walker ${ }^{5}$ considered in-situ bacterial oxidation of organic matter during early diagenesis to be the primary source of ${ }^{13} \mathrm{C}$-depleted carbon. Because of the autocorrelation observed between carbonate ${ }^{12} \mathrm{C}$ and abundance of magnetite, Baur et al. ${ }^{5}$ also suggested that the rhythmic pattern resulted from the dependence of the extent of ${ }^{13} \mathrm{C}$-depleted $\mathrm{CO}_{2}$ production, by in-situ bacterial oxidation, to the availability of $\mathrm{Fe}^{3+}$. Presumably, $\mathrm{Fe}^{3+}$ acted as the electron acceptor for the bacterial oxidation of organic matter 5,6 . Although this mechanism would appear to account for the $\delta^{13} \mathrm{C}$ pattern, no explanation has been presented for how the same process would result in a correlated $\delta^{18} 0$ pattern.

The $\delta^{18} 0$ value of carbonate is controlled by the $\delta^{18} 0$ value of the coexisting water. In the scenario envisioned by Walker ${ }^{5}$ and Baur et al. ${ }^{6}$, where carbonate precipitation occurred below the sediment/water interface, the $\delta^{18} 0$ value of the pore water would have controlled the $\delta^{18} 0$ value of the carbonate. 
What controlled $\delta^{18} 0$ variation in this pore water? If the site of in-situ bacterial oxidation proposed was shallower than about 100 meters, it is unlikely that the pore water $\delta^{18} 0$ value could have been significantly different from that of the overlying water column. At greater depths, precipitation of ${ }^{18} 0$-rich diagenetic minerals and increasing temperature of oxygen isotope exchange can lower the $\delta^{18} 0$ value of the pore water. However, these reactions can only result in an overall decrease in porewater $\delta^{18} 0$ with depth, not the finer-scale rhythmic variation observed in BIF 11,12 . As pointed out by Baur et al.6. deep burial diagenesis and low-temperature metamorphism are also unlikely to promote these finer-scale isotopic variations.

The autocorrelation observed between $\delta^{13} \mathrm{C}$ of the carbonate and organic carbon fractions and the relation between organic carbon abundance and isotopic composition (Figure $2 g, i, j$ ) are similarly difficult to reconcile with existing explanations for the rhythmic isotopic patterns for BIF.

The chemical and isotopic variations in BIF are most consistent with a model that involves episodic mixing between two reservoirs: resident sea water and external water. In this model, carbonate and silica precipitation occur in the water column at all times; the mineralogical and chemical variations result primarily from the variable supply of solutes (Si, Fe, etc.) to the water column. Without input of external water, the chemical and isotopic makeup of this water column is determined by normal processes that occur in sedimentary basins. This chemical and isotopic makeup is perturbed by introduction of the external water, depending on the extent of mixing between the resident and external water. Whereas such mixing processes have cominonly 
been proposed to explain BIF formation in general $9,14,15$, our results indicate that specific isotopic characteristics not hitherto attributed to the mixing process are quite consistent with it. In our proposed model, the chemical and isotopic characteristics of the resident sea water and the external water are reflected by the characteristics of the carbonate- and quartz-rich bands, respectively.

It is not possible to argue that precipitates from pure end-members of either of the two reservoirs are represented in the specific sample studied, hence it is best to speak only of the relative characteristics of the resident and external water. An obvious contrast between the external water and the resident sea water is the greater concentration of $\mathrm{SiO}_{2}$ in the external water as reflected by the higher silica/carbonate ratio. A lower $\mathrm{Mg} / \mathrm{Fe}$ ratio in the external water is indicated by the lower $\mathrm{Mg} / \mathrm{Fe}$ ratio in the quartz-rich band. The external water is therefore more ferriferous than the resident sea water. A steady increase in the Mg/Fe ratio from the base of the quartz-rich band to the base of the next overlying quartz-rich band (Figure $2 \mathrm{e}$ ) is suggestive of the preferential early incorporation of $\mathrm{Fe}$ in siderite and the consequent increase of $\mathrm{Mg} / \mathrm{Fe}$ in the residual solution 9,13 . The introduction of the next pulse of external water, marked by the appearance of the next quartz-rich band, appears to have truncated this gradual $\mathrm{Mg} / \mathrm{Fe}$ variation.

The external water is more depleted in ${ }^{18} 0$ and carries carbon that is more depleted in ${ }^{13} \mathrm{C}$ than the resident sea water, and this difference is responsible for the rhythmic isotopic variation in the carbonates. The autocorrelated variation in the $\delta^{13} \mathrm{C}$ values of the organic and carbonate carbon fractions may reflect primary dependence of organic matter isotopic 
composition on the isotopic composition of the $\mathrm{CO}_{2}$ substrate for carbon fixation ${ }^{13}$. This autocorrelation further support the suggestion that the observed rhythmic isotopic patterns were established by processes that occurred within the water column. The slight enhancement of total organic carbon content in the quartz-rich bands may also indicate that the influx of the external water is accompanied by enhanced biologic productivity.

The eventual source of the ${ }^{13} \mathrm{C}$ - and ${ }^{18} 0$-depleted external water cannot be fully addressed on the basis of the data presented here, but a contribution from recycled organic matter seems inescapable ${ }^{3-6}$. Biologically-mediated processes, such as those suggested by Baur et al. ${ }^{6}$ and Walker ${ }^{5}$, may well have been operative at the site where ${ }^{13} \mathrm{C}$-depleted $\mathrm{CO}_{2}$ was acquired by the external water. Numerous possible candidate sources of the external water have been discussed in the BIF literature; these include deep upwelling seawater ${ }^{2,10}$, fluvially-supplied water ${ }^{9}$, groundwater ${ }^{17}$, "exhaled" hydrothermal or diagenetic water ${ }^{18-20}$ and mantle/volcanic fluids. A deep upwelling seawater source as advocated by some 2,16 would seem unlikely to provide isotopically very different oxygen than the resident sea water. Interestingly, examples of water with the requisite isotopic characteristics for this external water have been postulated in some younger systems. Lawrence and Taviani ${ }^{21}$ noted the existence of cerbonates with extremely depleted ${ }^{13} \mathrm{C}$ and ${ }^{18} \mathrm{O}$ from the Norwegian Sea, which they attribute to the oxidation of $\mathrm{CH}_{4}$, and shallow oxygen isotope exchange between water and oceanic crust. More detailed isotopic and trace element studies of the isotopic and chemical heterogeneity of microbanded BIF offer promise in identifying the source of external water. 


\section{REFERENCES}

1 Schopf, J. W. Earth's Earliest Biosphere: Its Origin and Evolution (Princeton University Press, 1983) $531 \mathrm{pp}$.

2 Holland, H. D. The Chemical Evolution of the Atmospheres and Ocean (Princeton University Press, 1984) $582 \mathrm{pp.}$

3 Becker, R. H. and Clayton, R. N. Geochim. Cosmochim. Acta 36, 577-595 (1972) .

4 Perry, E. C., Tan, F. C. and Morey, G. B. Econ. Geol. 68, 110-1125 (1973). 5 Walker, J. C. G. Nature 309, 340-342 (1984).

¿ Baur, M. E., Hayes, J. M., Studley, S. A. and Walter, M. R. Econ. Geol. 80, 270-282 (1985) .

7 Walker, J.C. G., Klein, C., Schidlowski, M, Schopf, J. W., Stevenson, D. J. and Walter, M. R. in Earths Earliest Biosphere, Its Origin and Evolution (ed. Schopf, J. W.) 260-290 (1983).

8 Baker, A. J. and Fallick, A. E. Geochim. Cosmochim. Acta 53, 1111-1115 (1989) .

9 Garrels, R. M. Am. Jour. Science 287, 81-106 (1987).

10Abrajano, T. A., Holt, B. D. and Dyrkacz, G. R. Org. Geoch. (in press). ${ }^{11}$ Curtis, C. D., Coleman, M. L. and Love, L. G. Geochim. Cosmochim. Acta 50, 2335-2348 (1986) .

${ }^{12}$ Longstaffe, F. J. in Stable Isotope Geochemistry of Low Temperature Fluids (ed. Kyser, T. K.) 187-257 (1987).

13Hayes, J. M., Popp, B. N., Takigiku, R. and Johnson, M. W. Geochim. Cosmochim. Acta 53, 2961-2972 (1989).

${ }^{14}$ Trenda11, A. F. and Blockley, J. G. West. Aust. Geol. Surv. Bull. 119, 336 pp (1970) . 
${ }^{15}$ Ewers, W. E. and Morris, R. C. Econ. Geol. 76, 1929-1953 (1981).

${ }^{16}$ Drever, J. I. Geol. Soc. Am. Bull. 85, 1099-1106 (1974).

17 James, H. L. in Data of Geochemistry (ed. Fleischer, M.), 1-61 (1966).

${ }^{18}$ Goodwin, A. M., Thode, H. G., Chou, C.-L. and Karkhansis, S. N. Can. J. Earth Sci., 22, 72-84.

${ }^{19}$ Simonson, B. M. Geol. Soc. Am. Bul1. 96, 244-252.

${ }^{20}$ Fryer, B. J., in Iron Formation: Facts and Problems (eds. Trendal1, A. F. and Morris, R. C.). 345-38 (1983).

${ }^{21}$ Lawrence, J. R. and Taviani, M. Geochim. Cosmochim. Acta. 52, 2077-2083 (1988) .

ACKNOWLEDGEMENTS. This work was supported by the Department of Energy, Office of Basic Energy Sciences. The Minnesota Department of Natural Resources and Pickands Mather, Inc. are thanked for access to BIF samples. T. L. Day prepared some of the samples. B. Tani and R. Couture performed the XRD characterization and E. Huff performed the ICP-AES analyses. This manuscript benefited from an early review by N. C. Sturchio. 
Figure Captions:

Figure 1. Photograph of microbanded sample MDD 5-924. Dark bands are quartzdominated and light bands are siderite-dominated (see text for detailed mineralogy). Sample is oriented similar to orientation upon sedimentary deposition. Numbers 1 to 9 correspond to bands visible in hand sample.

Figure 2. Chemical and isotopic variations across sample MDD 5-924. Horizontal scale are sample numbers from bottom (left) to top (right). Band numbers correspond to those shown in Figure 1. Elemental units including TOC and TCC are weight per cent, $\delta^{13} \mathrm{C}$ values are per mil deviation from standard Pee Dee Belemnite, and $\delta^{18} 0$ values are per mil deviation from Standard Mean 0cean Water. TCC - total carbonate carbon; TOC - total organic carbon. 


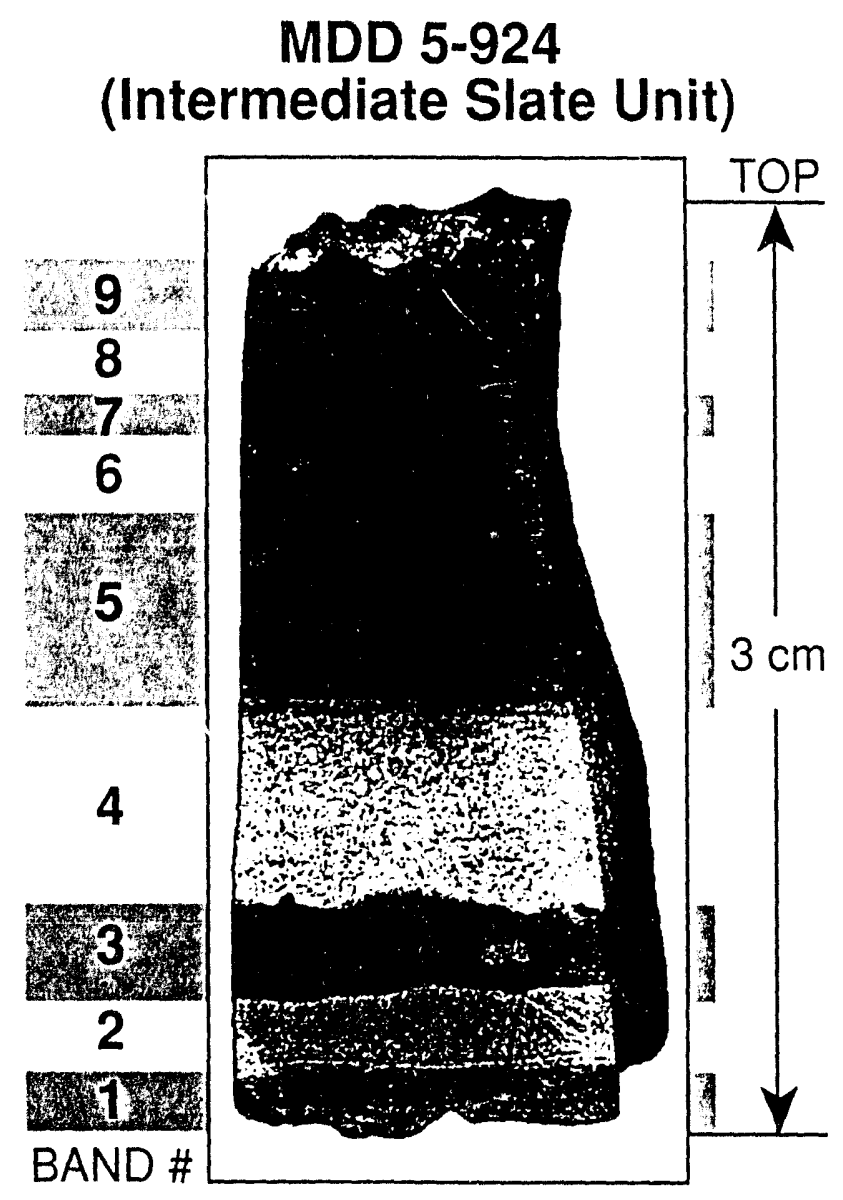




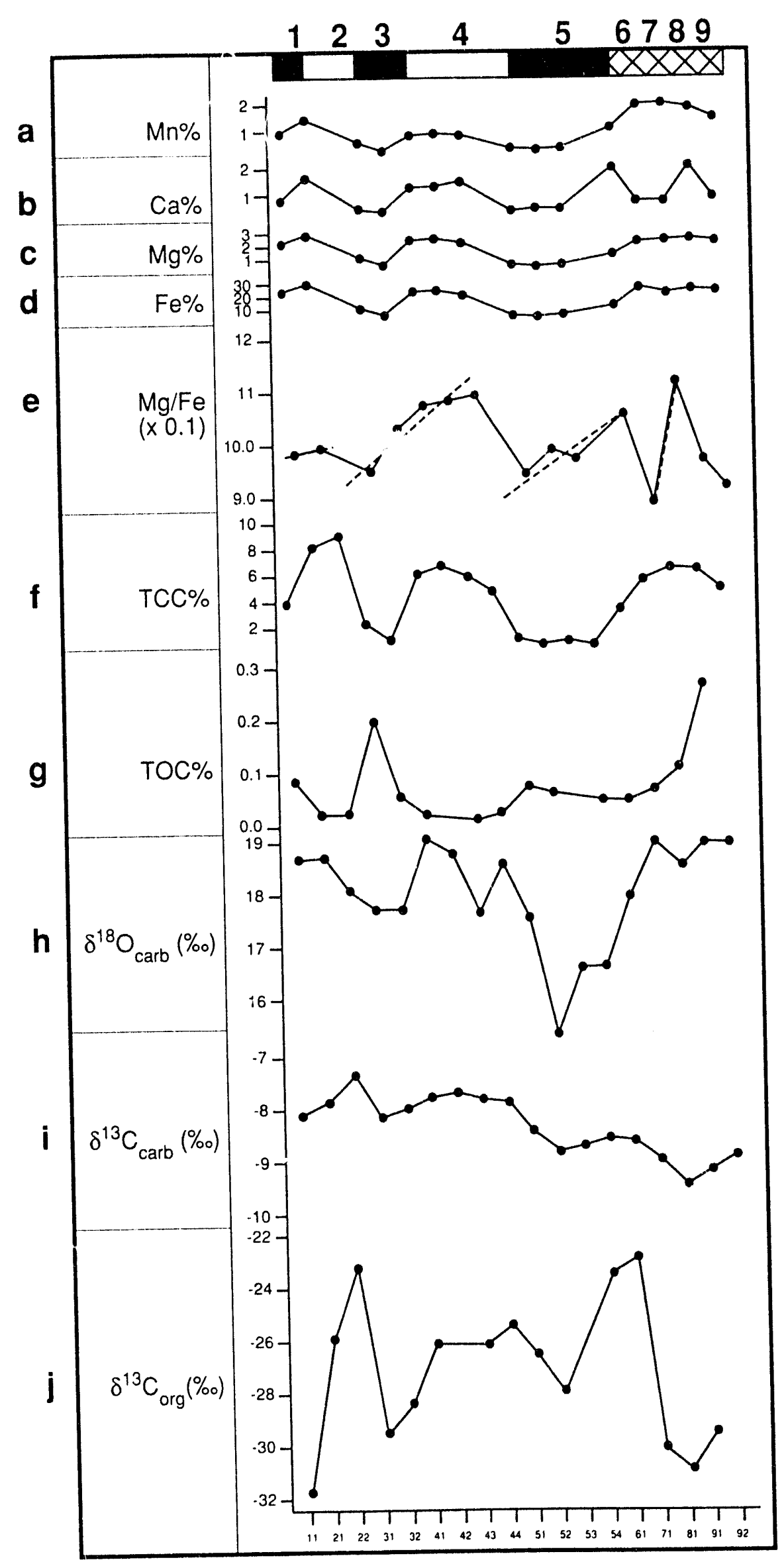



